\title{
The conservation status of key bird species on Taliabu and the Sula Islands, Indonesia
}

\author{
PETER DAVIDSON, TONY STONES and ROB LUCKING
}

\section{Summary}

Ornithological surveys were conducted over a seven-week period on Taliabu, Sula Islands, Indonesia in 1991, concentrating on eight species (seven of which have restricted ranges) considered (in 1991) to be threatened and six species (two of which have restricted ranges) considered near-threatened. All of the restricted-range species are dependent on lowland forest, although most persist in secondary habitats, and some also occur in montane forest. Tyto nigrobrunnea was recorded for the first time since the type-specimen was collected in 1938, and is perhaps the most threatened of all the restricted-range birds. Megapodius bernsteinii, Pitta dohertyi, Rhinomyias colonus, Basilornis galeatus and Streptocitta albertinae are threatened in the longer term, primarily by habitat loss. Both Coracina schistacea and $C$. sula are able to persist in all but the most degraded of habitats. Of the two restricted-range species considered near-threatened, Zoothera erythronota is at greatest risk on Taliabu, apparently restricted to lowland forests. The other, Ptilinopus subgularis, is common in lowland forest and also occurs in montane forest. Little primary lowland forest was found in the areas visited on the island, and identifying remaining areas of this forest type and its relative importance to the birds, especially restricted-range species, should be given highest priority in further surveys. The suitability of a proposed reserve area on the island was evaluated: a larger area of lowland forest than is currently proposed should be afforded protection in order to safeguard the island's characteristic avifauna.

\section{Introduction}

The Sula Islands, which comprise Taliabu, Mangole and Sanana, form the westernmost island group in Maluku Province, Indonesia (Figure 1). Taliabu $\left(c .1^{\circ} 80^{\prime} \mathrm{S} 124^{\circ} 60^{\prime} \mathrm{E}\right.$ ) is the largest and covers a total land area of $c .3,000 \mathrm{~km}^{2}$. As part of the Food and Agriculture Organization/United Nations Development Programme's National Conservation Plan for Indonesia (FAO/UNDP 1981), recommendations were made for a proposed cagar alam (strict nature reserve) on Taliabu, in order to provide protection for the endemic flora and fauna, and to preserve water catchment on the island. This proposed reserve covers an area of $c .900 \mathrm{~km}^{2}$ (see Figure 3), and extends from the mountainous spine (highest peak $1,649 \mathrm{~m}$ ) down to the northern shores of the island.

In a recent analysis identifying areas of global avian endemism, ICBP (1992) delimited 24 Endemic Bird Areas (EBAs) in Indonesia. Taliabu is encompassed within the Banggai and Sula Islands EBA (E22) (see Figures 1 and 2). EBAs have been prioritized in terms of biological importance (i.e. number of restrictedrange species and taxonomic uniqueness) and scale of threat (i.e. threats to 


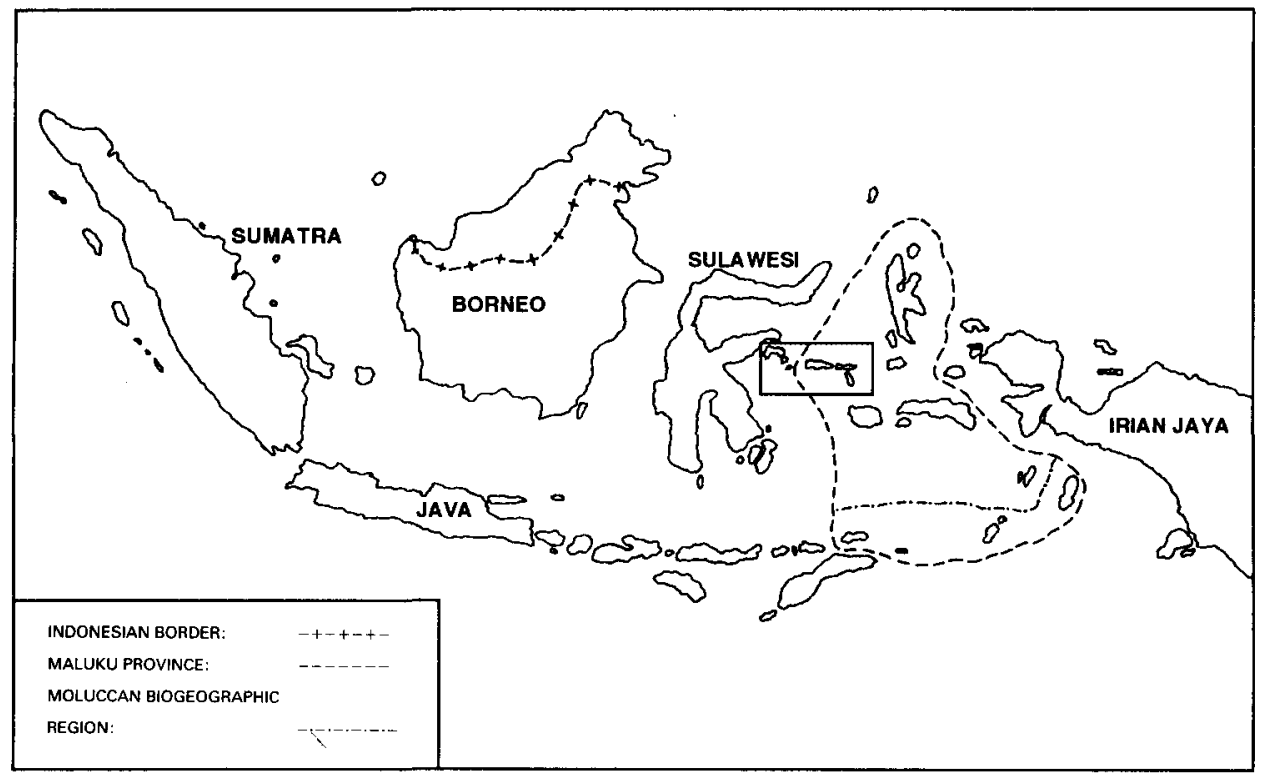

Figure 1. The location of the Banggai and Sula Islands.

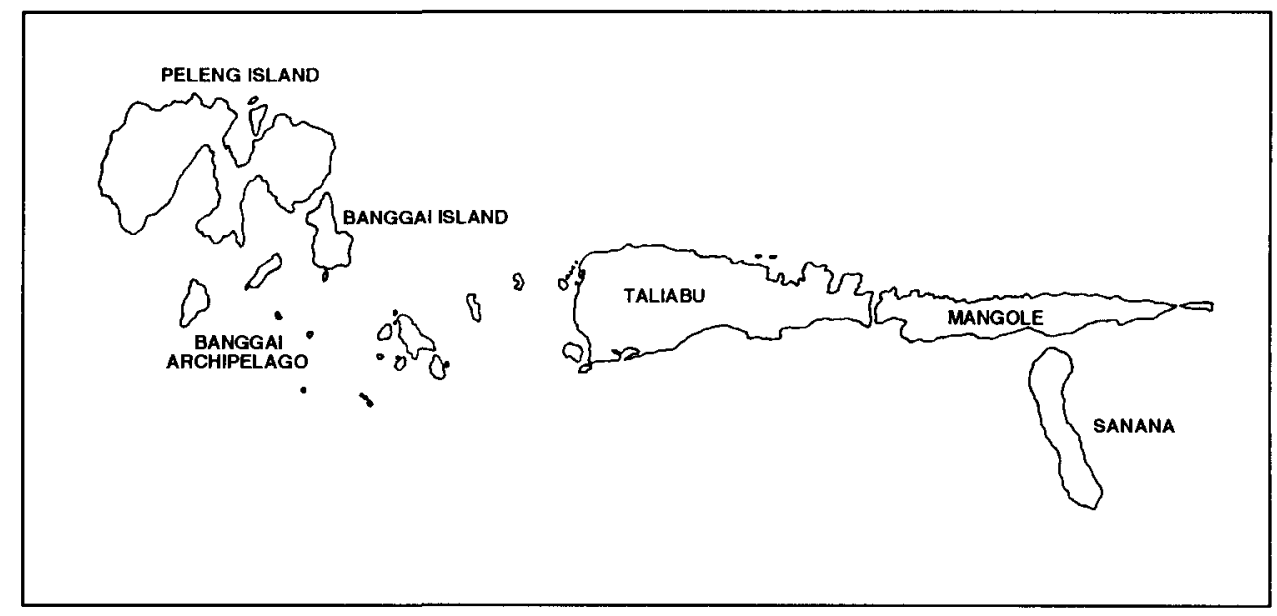

Figure 2. The Banggai and Sula Islands Endemic Bird Area (see box in Figure 1 above).

birds and total areas currently afforded protection), and categorized into three groups of priority for conservation: critical, urgent and high (ICBP 1992). The Banggai and Sula Islands EBA is given critical priority in this analysis.

The Banggai and Sula Islands EBA contains 17 restricted-range bird species, nine of which are confined to the EBA (White and Bruce 1986, Stattersfield et al. in prep.). Nine of the restricted-range species are listed by Collar and Andrew (1988) as being globally threatened with extinction. Seven of these occur on Taliabu. 
The continued existence of most of these key species on the Sula Islands was only confirmed in 1988 (D. Yong in litt. to BirdLife International). In September and October 1991 a survey comprising personnel from the University of East Anglia, BirdLife International (formerly the International Council for Bird Preservation), the Directorate General for Forest Protection and Nature Conservation (PHPA) and the Indonesian Institute of Sciences (LIPI) carried out fieldwork on Taliabu to assess these birds' status and broad habitat preferences, and aimed to use the results as a basis from which to make recommendations concerning the delimiting of the boundaries of a proposed nature reserve on the island (Davidson et al. 1994).

A total of 48 days was spent on Taliabu. Thirty-one days were spent at Menanga Base Camp, six days in the montane protection forest, four days at Bobong and six days on Pulau Seho. In addition three expedition personnel spent three days at Tubang and four days around Hol Kemuning. A total of 73.3 hours was spent carrying out survey work, 13.3 hours of which were spent in montane forest, 4.4 hours in primary lowland forest, 22.6 hours in selectively logged lowland forest, 19.5 hours in heavily degraded lowland forest, 10.8 hours in agricultural areas and 2.7 hours in reedswamp. In addition brief visits were made to the immediate environs of Sanana village, on two dates either side of the study period, and five full days were spent in and around Falabisahaya, Mangole, mostly after the study period.

\section{History of ornithological studies on Taliabu}

The Sula Islands are ornithologically among the least known of the Moluccan group. Most visits to the islands by explorers and specimen collectors around the turn of the century are very poorly documented in terms of specific location, habitat and altitude. The first ornithological observations from the Sula group were documented by Alfred Russel Wallace (Wallace 1862). Owing to ill health, he was not able to visit the islands himself, but arranged for his assistant, C. Allen, to collect specimens on his behalf. In total, Allen collected 48 bird species from Sanana and Mangole, but did not visit Taliabu. At that time seven of the species collected were considered by Wallace to represent species new to science. However, taxonomic developments since that period have resulted in the accreditation of only two of these, Moluccan Hanging-parrot Loriculus amabilis and Yellow-and-green Lorikeet Trichoglossus flavoviridis. Somewhat surprisingly, perhaps, Allen did not collect any of the Sula Islands' endemic species.

Further visits by nineteenth-century collectors quickly followed. Table I presents a summary of ornithological exploration on the Sula Islands. H. A. Bernstein, "a doctor on Java" employed by the Rijksmuseum van Natuurlijke Historie (RMNH), Leiden, visited the islands in 1864 , and collected the type-specimen of Sula Scrubfowl Megapodius bernsteinii on Mangole. In 1938, J. J. Menden made the first documented ornithological observations from Taliabu itself. Menden's collection included the type-specimen of Taliabu Masked-owl Tyto nigrobrunnea, the only single-island endemic in the Banggai and Sula Islands EBA.

A 50-year lapse in ornithological recording then followed, finally terminated by Dennis Yong, a Malaysian ornithologist, who visited Sanana and Mangole 
Table 1. Summary of ornithological exploration on the Sula Islands

\begin{tabular}{lll}
\hline Name & Date & Locality visited \\
\hline C. Allen & 1862 & Mangole and Sanana \\
H. A. Bernstein & 1864 & Sula Islands (Mangole at least) \\
J. E. Teijsmann & 1877 & Sanana \\
F. H. H. Guillemard & 1883 & Sula Islands \\
W. Lucas & 1898 & Sula \\
F. Kopstein & 1924 & Sanana \\
J. J. Menden & 1938 & Taliabu (and Peleng) \\
D. Yong & 1988 & Mangole and Sanana \\
F. Smiet & 1990 & East Taliabu and Mangole \\
University of East Anglia Expedition & 1991 & Taliabu (north and west), Mangole and \\
& & Sanana \\
\hline
\end{tabular}

Data before 1980 s derived from White and Bruce (1986).

for a ten-day period in December 1988. Fred Smiet visited eastern Taliabu and Mangole on behalf of FAO for five days in October 1990. In addition, recent visits have been made to the neighbouring Banggai archipelago, in 1981 by D. Bishop, and in 1991 by M. Indrawan and co-workers (Indrawan et al. 1993).

\section{Habitats and land-use on Taliabu}

A substantial proportion of Taliabu is still forested (see Figure 3). However, since 1969/1970 large-scale logging of lowland forest has taken place, principally the selective logging of two economically valuable Shorea species (Smiet 1982), but also wholesale clear-felling of some areas for industrial timber production (monospecific stands of fast-growing species). Most forest below $c .800 \mathrm{~m}$ is now under logging concession, and commercial timber extraction forms the basis of the Sula Islands' economy.

In the lowlands (up to $c .700 \mathrm{~m}$ ) selective logging has produced a mosaic of different-aged forest stands. Although RePPProT (1989) maps indicate the

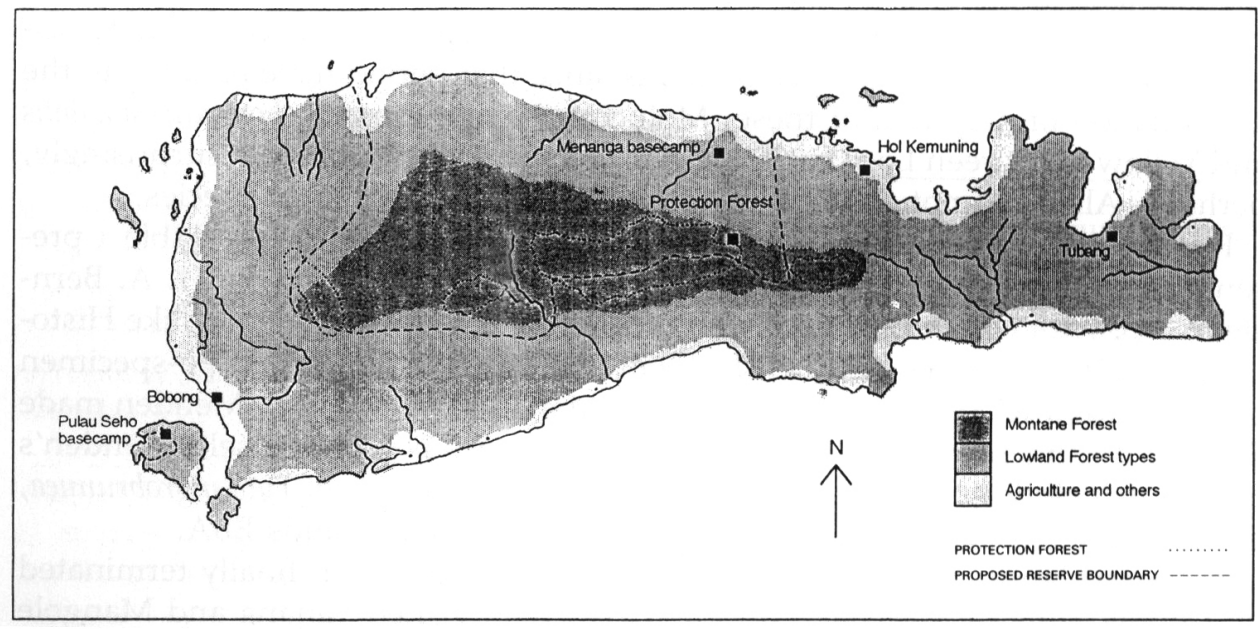

Figure 3. Approximate habitat/land-use zones on Taliabu. 
dominant habitat zones on Taliabu to be primary lowland and montane forest, much of the original primary lowland forest has already been logged over at least once. There appear to be few, if any, extensive tracts of primary lowland forest remaining, except perhaps in the central south-west of the island. Coastal forest apparently still exists in the north-east of the island (RePPProT 1989).

Above $c .800 \mathrm{~m}$ the forest changes character and grades into montane forest, most of which is designated as "Protection Forest", a term which refers to forest protected from commercial logging but not from local shifting agriculture. Much, if not all, of this zone remains undisturbed. Only c. $18 \%$ of the lowland forest on Taliabu is currently encompassed within the boundaries of the $c .900 \mathrm{~km}^{2}$ proposed reserve area, whereas most $(c .85 \%)$ of Taliabu's montane forest (already protected) is included in this zone. In addition, a c.1,250 ha cagar alam was established in 1972 on Pulau Seho, a small island off the south-west coast of Taliabu.

Patches of cultivation, both shifting and permanent, can be found close to the coast, concentrated around local settlements. Many local people derive their income from low-intensity cash crops, in particular cloves Eugenia aromatica. Narrow strips of tidal forest (mangrove) can be found along much of the coastline, interspersed with sandy beaches.

\section{Key species}

This section deals with the eight species which occur on Taliabu and were considered by Collar and Andrew (1988) to be globally threatened with extinction (Table 2), together with the six listed as near-threatened (Table 3), and Sula Pitta Pitta dohertyi. Seven of the eight species considered threatened are endemic to the Banggai and Sula Islands EBA (and hence of restricted range), as is Sula Pitta. Collar et al. (1994) have revised the global status of these species in the light of our data and that from other recent sources, and the new status is given in each species account. Also included are three additional species present on Taliabu that are now considered by Collar et al. (1994) to be near-threatened; none of these has a restricted range.

Recent authors afford Sula Pitta full species status (Sibley and Monroe 1990, Lambert in prep.). It was formerly treated as a race of Blue-breasted Pitta $P$. erythrogaster, e.g. by White and Bruce (1986). Sula Pitta is a restricted-range species confined to the Banggai and Sula Islands EBA (Stattersfield et al. in prep.). In keeping with those species listed above, which are endemic to the Banggai and Sula Islands EBA and considered threatened owing to their restricted ranges, Sula Pitta is also best considered threatened, and is treated as such throughout this paper.

Neither Bald-faced Rail Gymnocrex rosenbergii nor Banggai Crow Corvus unicolor has been recorded on the Sula Islands.

Six species considered by Collar and Andrew (1988) to be near-threatened occur in the Banggai and Sula Islands EBA. Two of these are range-restricted, Maroon-chinned Fruit-dove Ptilinopus subgularis and Red-backed Thrush Zoothera erythronota.

A number of techniques, principally the variable circular plot method (Reynolds et al. 1980 with modifications following Jones et al. 1994) 
Table 2. Threatened birds (listed by Collar and Andrew 1988) of the Banggai and Sula Islands EBA and their distributions

\begin{tabular}{|c|c|}
\hline Species & Distribution \\
\hline $\begin{array}{l}\text { Sula Scrubfowl Megapodius } \\
\text { bernsteinii }\end{array}$ & Endemic to the Sula Islands, Banggai and Peleng \\
\hline $\begin{array}{l}\text { Bald-faced Rail Gymnocrex } \\
\text { rosenbergii }\end{array}$ & Endemic to Peleng and the Sulawesi lowlands EBA (E2I) \\
\hline $\begin{array}{l}\text { Nicobar Pigeon Caloenas } \\
\text { nicobarica }\end{array}$ & $\begin{array}{l}\text { Nicobar and Andaman Islands, and islands east through } \\
\text { Indonesia and the Philippines to Papua New Guinea, the } \\
\text { Solomons and Palau }\end{array}$ \\
\hline $\begin{array}{l}\text { Taliabu Masked-owl Tyto } \\
\text { nigrobrunnea }\end{array}$ & Endemic to Taliabu \\
\hline $\begin{array}{l}\text { Slaty Cuckoo-shrike Coracina } \\
\text { schistacea }\end{array}$ & Endemic to the Sula Islands, Banggai and Peleng \\
\hline Sula Cicadabird Coracina sula & Endemic to the Sula Islands \\
\hline $\begin{array}{l}\text { Henna-tailed Jungle-flycatcher } \\
\text { Rhinomyias colonus }\end{array}$ & Endemic to the Sula Islands and Peleng \\
\hline $\begin{array}{l}\text { Helmeted Myna Basilornis } \\
\text { galeatus }\end{array}$ & Endemic to the Sula Islands, Banggai and Peleng \\
\hline $\begin{array}{l}\text { Bare-eyed Myna Streptocitta } \\
\text { albertinae }\end{array}$ & Endemic to the Sula Islands \\
\hline Banggai Crow Corous unicolor & Endemic to Banggai \\
\hline
\end{tabular}

Sources: White and Bruce (1986), Collar and Andrew (1988), Davidson et al. (1991), ICBP (1992), Indrawan et al. (1993), Stattersfield et al. (in prep.).

Table 3. Near-threatened species (listed by Collar and Andrew 1988) of the Banggai and Sula Islands EBA

\begin{tabular}{ll}
\hline Species & Distribution \\
\hline Great-billed Heron Ardea sumatrana & South-East Asia, Nicobars, Greater Sundas and \\
& Philippines to Australia \\
Malay Sandplover Charadrius peronii & Philippines, west Malaysia and Indonesia \\
& (Sulawesi, Lesser and Greater Sundas) \\
Little Curlew Numenius minutus & Breeds North-East Asia and winters south \\
& Papua New Guinea to Australia. Passage Japan, \\
Maroon-chinned Fruit-dove Ptilinopus & Philippines and east Indonesia \\
subgularis & Endemic to Sulawesi, the Sula Islands, Banggai \\
Elegant Pitta Pitta elegans & and Peleng \\
& Endemic to the Moluccas, Lesser Sundas and \\
Red-backed Thrush Zoothera erythronota & islands off Sulawesi \\
\hline
\end{tabular}

Sources: White and Bruce (1986), Collar and Andrew (188), Davidson et al. (1991), ICBP (1992), Stattersfield et al. (in prep.).

complemented by basic encounter rates, were used to survey bird communities in different habitats. Full analyses of these results are presented elsewhere (Davidson et al. 1994). The remainder of this section aims to summarize each species's status and broad habitat preferences, coupled with other relevant ecological and behavioural details.

\section{Great-billed Heron Ardea sumatrana}

Status on Sula Islands Apparently a scarce resident. Only three were recorded during the study period, one at Hol Kemuning, on the north coast of Taliabu, 
the other two at Falabisahaya on the north-west coast of Mangole (all adults). The records from Mangole constitute the first for the island. Menden collected a female on Taliabu in 1938 (White and Bruce 1986), the only previous record from the Sula Islands.

Habitat preferences Usually found in coastal mangroves, mudflats, creeks and coral reefs (White and Bruce 1986), with the majority of records from small islands. Disturbance is suggested as one of the main reasons for the species's decline in certain parts of its extensive range (Marchant and Higgins 1990). The bird on Taliabu was on mangrove fringe, whilst those on Mangole frequented a log pond adjacent to a plywood factory. No evidence of breeding was found.

Conservation status Listed as near-threatened by Collar et al. (1994). White and Bruce (1986) postulate that this species has a sparse distribution throughout Wallacea. Presumably it also only occurs at low densities on Taliabu, although mangroves were not comprehensively surveyed during the study. The narrow strips of mangrove found along much of the northern and western coastlines of Taliabu did not appear to be under threat from disturbance or removal, except for those in the immediate vicinity of logging camps (where the only Great-billed Herons were seen). Thus, although it probably occurs only at low densities, at present the species is probably not under immediate threat, on Taliabu at least.

Jerdon's Baza Aviceda jerdoni

Status on Sula Islands Probably a scarce resident. Only two individuals were recorded during the study period, both inland from Bobong in south-west Taliabu.

Habitat preferences Both individuals were observed in selectively logged lowland forest. In Sulawesi found inside and on the edge of mountain forest and over mountain grassland (White and Bruce 1986).

Conservation status Listed as near-threatened by Collar et al. (1994). Little is known about the status of this inconspicuous species on Taliabu, but it probably only occurs at low densities, and, although it may not currently be at risk, further logging activities can only be detrimental to the population.

\section{Lesser Fish-eagle Ichthyophaga humilis}

Status on Taliabu Probably a scarce resident. Two birds seen near Bobong were the only records.

Habitat preferences Taliabu records were from a substantial area of reedswamp near Bobong. An inhabitant of coasts and forested waterways (White and Bruce 1986). 
Conservation status Listed as near-threatened by Collar et al. (1994). Too little is known about the status of this species on Taliabu to assign a conservation status.

\section{Sula Scrubfowl Megapodius bernsteinii}

Status on Sula Islands Locally common resident. Encountered regularly in central-northern and south-western areas of Taliabu. In eastern Taliabu a local man said that Sula Scrubfowl, whilst previously present in the vicinity of Tubang, where much of the clear-felling for industrial timber production has taken place, was now extinct. Only one scrubfowl was recorded at Hol Kemuning, an extensive area of heavily degraded forest in close proximity to the coast. On Banggai it was encountered up to $450 \mathrm{~m}$ and described as "common but declining" in 1991 (Indrawan et al. 1993). It was noted by D. Yong on Mangole (but not Sanana) in 1988, where one bird was seen, and another heard, both in logged forest (Dekker 1990).

Habitat preferences The species occurs most commonly in lowland forest, particularly coastal areas. It also appears capable of tolerating low levels of disturbance at least, and was regularly found in dense scrub on the fringe of agriculture and heavily degraded forest (Lucking et al. 1992). Indrawan et al. (1993) discovered nest mounds in lightly wooded cultivation. Scrubfowls were not recorded above $c .250 \mathrm{~m}$ on Taliabu. However, R. Dekker (in litt.) suggests that megapode distribution may not be a function of altitude per se. Many megapode species appear to prefer forest habitats in close proximity to the coast, perhaps predetermined by their breeding requirements. The area of coastal forest in north-east Taliabu, if still intact, together with still forested satellite islands, may thus hold the highest densities of this megapode.

Conservation status Listed as threatened by Collar and Andrew (1988), revised to near-threatened (Collar et al. 1994). Apparently not immediately threatened on Taliabu, in part due to the fairly minimal impact of hunting/trapping and to the fact that this megapode appears not to be a communal mound-nester (Indrawan et al. 1993), which dramatically reduces its susceptibility to eggharvesting. However, it may well be restricted to the coastal zone, and is thus vulnerable to the impending threat of forest loss through commercial logging.

\section{Malaysian Plover Charadrius peronii}

Status on Sula Islands Presumably a scarce resident on the Sula Islands, as elsewhere in Wallacea (White and Bruce 1986), although previously unrecorded. No records from Taliabu, but one was seen near Falabisahaya, Mangole, on 2830 October. This constitutes the first record of the species for the Sula Islands.

Habitat preferences Favours sandy beaches, especially small bays with coralline sands (White and Bruce 1986). The bird on Mangole frequented a dead coral platform bordering a sandy beach. This site received regular disturbance, being a mere $200 \mathrm{~m}$ from the island's airstrip. Hayman et al. (1986) state that the 
species favours undisturbed sandy or coral beaches, and is occasionally found on mudflats.

Conservation status The apparent lack of suitable habitat suggests the species must have a sparse distribution on Taliabu at least, and would thus be at risk from any further habitat loss.

\section{Little Curlew Numenius minutus}

Status on Sula Islands Scarce migrant. Not encountered on Taliabu, the only observation being of a juvenile on the dry, grassy airstrip at Falabisahaya, Mangole, on 29 October. Menden collected one on Taliabu in autumn 1938 (White and Bruce 1986). The Little Curlew is a passage visitor to Wallacea, with few previous records. However, it is likely that the species uses the islands in this part of Wallacea as a regular migration stopover point, and has thus far been under-recorded. It is no longer considered to be near-threatened (Collar et al. 1994).

\section{Nicobar Pigeon Caloenas nicobarica}

Status on Sula Islands Scarce, presumably resident. Nicobar Pigeons are known to perform short-distance inter-island migrations (Collar and Andrew 1988), so it is difficult to ascribe status with any certainty. Only four birds were recorded on Taliabu during the study period, all around Menanga base camp. These constitute the first records for the Sula Islands. Two birds were seen in selectively logged forest ( $c .50 \mathrm{~m}$ ), and another two were trapped by local people using snares. In addition, a bird was being offered for sale at Falabisahaya, Mangole, on 29 October. Our guide informed us that he had seen the species in mangroves on Pulau Seho.

Habitat preferences Nicobar Pigeons are evidently able to persist in secondary habitats. Both field observations were in selectively logged lowland forest. However, it is possible that they may occur (and breed) more commonly on Taliabu's undisturbed, forested satellite islands, which may also hold numbers of Sula Scrubfowl.

Conservation status Listed as threatened by Collar and Andrew (1988), revised to near-threatened (Collar et al. 1994). Human population pressure has increasingly threatened this species across much of its range (Collar and Andrew 1988), through habitat loss together with associated increases in hunting activities. At present the Nicobar Pigeon is at risk from both of these threats on Taliabu.

\section{Maroon-chinned Fruit-dove Ptilinopus subgularis}

Taxonomic status Represented on the Sula Islands by an endemic subspecies $P$. s. mangoliensis, one of three subspecies of this restricted-range columbid. 
Status on Sula Islands Common and widespread resident, found from sea level to at least $900 \mathrm{~m}$. Five specimens collected on Taliabu, three by Doherty (Hartert 1898) and two by Menden in 1938 (White and Bruce 1986), appear to be the only previous records from the island.

Habitat preferences Most abundant in lowland forest, especially the less disturbed tracts, but also regularly encountered in degraded forest and forest/ agriculture fringe; noted in montane forest at much lower densities. We found it to be a very vocal species which generally feeds in the canopy of large fruiting trees, often associating and flocking with Black-naped Fruit-doves P. melanospila. On Sulawesi it is found in lowland forest, but only up to $600 \mathrm{~m}$ (White and Bruce 1986).

Conservation status Listed as near-threatened by Collar and Andrew (1988), but no longer considered at risk (Collar et al. 1994). Not presently at risk on Taliabu, although its apparent preference for the less disturbed lowland forest types suggests the population will come under increasing pressure from large-scale logging operations:

\section{Moluccan King-parrot Alisterus amboinensis}

Taxonomic status Represented in the Sula Islands by an endemic subspecies A. a. sulaensis.

Status on Sula Islands Widespread but uncommon on Taliabu. Confined to forest more than the other Psittacidae on the Sula Islands.

Habitat preferences Most frequent in the least disturbed tracts of lowland forest. Very rarely encountered in heavily degraded forest and not recorded at all outside forest. Recorded in low densities in montane forest. Found in lowland forest up to 1,400 $\mathrm{m}$ (White and Bruce 1986).

Conservation status Apparently not presently at risk on Taliabu but the lowland populations could come under increasing pressure through commercial logging activities. At present there appears to be no threat from hunting or trapping for the cagebird trade.

\section{Taliabu Masked-owl Tyto nigrobrunnea}

Status on Taliabu Considered to be a very rare and/or elusive resident, endemic to Taliabu. Only one bird was seen, spotlighted along a logging track $c .2 \mathrm{~km}$ from Tubang in the mid-evening of 3 October. This constitutes the first record of the species since the type-specimen, a female, was collected by Menden in 1938. Other forest-dwelling members of this genus are sparsely distributed, shy and easily overlooked (Bishop 1989). However, given its nocturnal habits and the fact that it appeared not to call during night fieldwork (no calls were heard which could be attributed to the species), it may have been under-recorded. 
Habitat preferences The individual seen was in selectively logged lowland forest. Taliabu Masked-owl presumably requires forest for feeding and nesting. On Sulawesi its close relative, Minahassa Owl T. inexspectata, also a forest-dwelling species, has been found breeding in April, two birds frequenting a nest-hole in a tree (Bishop 1989). However, Minahassa Owl is still very poorly known, and the lack of records of this species has been attributed to habitat destruction (Bishop 1989). The status of and effects of habitat degradation on Taliabu Masked-owl urgently need to be determined.

Conservation status Listed as threatened by Collar and Andrew (1988), and now classified as Vulnerable (Collar et al. 1994). Taliabu Masked-owl is perhaps the most threatened of all the restricted-range birds found on the islands. Future surveys should prioritize an assessment of this owl's true status and habitat requirements. These should also aim to cover the neighbouring island of Mangole, where there may be an undiscovered population of the species.

\section{Sula Pitta Pitta dohertyi}

Taxonomic status Sula Pitta was formerly treated as a race of Blue-breasted Pitta $P$. erythrogaster, a complex species split into ten separate subspecies within Wallacea alone (White and Bruce 1986), and occurring from the Philippines through to north-east Australia.

Status on Sula Islands Uncommon resident, although perhaps under-recorded owing to its unobtrusive nature and the fact that birds were not heard calling for much of the study period. One presumed juvenile bird was seen in selectively logged lowland forest on Pulau Seho on 19 October. Four birds were collected on Peleng by Menden in 1938 and Bishop recorded this species on Banggai in November 1981 (White and Bruce 1986). An immature has been collected on Mangole (White and Bruce 1986), but no date was given.

Habitat preferences All observations were of individuals in secondary lowland forest types. In the more heavily degraded tracts, birds appeared to favour areas where large stands of bamboo predominate. White and Bruce (1986) state that the race of Blue-breasted Pitta on Sulawesi, P. e. celebensis, is a lowland species found up to $1,000 \mathrm{~m}$. We did not record Sula Pitta above $c .200 \mathrm{~m}$ on Taliabu.

Conservation status Considered near-threatened by Collar et al. (1994). The effects of habitat destruction on the species require further investigation, although it obviously tolerates some secondary habitats. The apparent altitudinal restriction on Taliabu, to regions below $c .200 \mathrm{~m}$, indicates that it may be under more threat than our records suggest. Assuming that full species status becomes widely accepted, Sula Pitta should be considered threatened in the category Vulnerable.

\section{Elegant Pitta Pitta elegans}

Taxonomic status Five subspecies are recognized, almost exclusively confined to Wallacea (it is not, however, a restricted-range species). The nominate P. e. 
elegans occurs on the Sula Islands, as well as Buru, Ternate, Seram, Timor and neighbouring islands in the Lesser Sundas, and two small islands off north-east Sulawesi. Migratory movements have been suggested in two races, including P. e. elegans.

Status on Sula Islands Apparently scarce. Seen at two sites, records only involving five birds. These constitute the first records of Elegant Pitta for Taliabu. It was not noted until 11 October, over a month into the study period, which coincides with the only other dated record from Mangole (White and Bruce 1986). It is therefore possible that the species is a migrant to Taliabu. The majority of records involved calling birds, with a maximum of three calling together at Menanga base camp. The species perhaps went under-recorded, as it often calls only briefly at dawn and dusk (Gibbs 1990, pers. obs.).

Habitat preferences Found in similar habitats to its congener Sula Pitta, although perhaps more tolerant of heavily degraded forest and dense scrub on forest/ agriculture fringes. Gibbs (1990) notes it as being very common in dense secondary habitats, but that it can be impossibly elusive. In the Lesser Sundas, the species has been found in forest edges, woodland and thickets up to $1,000 \mathrm{~m}$ (White and Bruce 1986).

Conservation status The bird's status on the Sula Islands needs clarification, though during the period of study on the island it seemed to be scarce. This species is no longer considered near-threatened (Collar et al. 1994).

\section{Slaty Cuckoo-shrike Coracina schistacea}

Status on Sula Islands Common resident, found from sea level to $900 \mathrm{~m}$ at least. Indrawan et al. (1993) described it as "not uncommon" in the Banggai archipelago. D. Yong (in litt.) found it to be common on Mangole, and also recorded it on Sanana. Menden collected four specimens from Taliabu and three from Peleng in 1938 (White and Bruce 1986).

Habitat preferences Apparently most abundant in agriculture/forest fringe, but also common in secondary lowland forest types, and apparently able to tolerate all but the most degraded of habitats (e.g. clear-felled areas). Considerably less common in montane forest. Common in logged forest on Mangole, and seen in secondary forest on Sanana in 1988 (D. Yong in litt.). Observed singly or in groups of up to three birds, generally frequenting the mid-canopy and above, or the taller trees in agriculture, and seldom noted in association with any other species. Thus, perhaps it was under-recorded in the less disturbed forest types. Usually seen in small family parties on Mangole in December 1988 (D. Yong in litt.).

Conservation status Listed as threatened by Collar and Andrew (1988), but no longer considered to be at risk (Collar et al. 1994). One of the commonest of the restricted-range birds on Taliabu, it is not threatened at present. 


\section{Sula Cicadabird Coracina sula}

Status on Sula Islands - Common resident, found from sea level to at least $900 \mathrm{~m}$, although only two individuals were recorded in montane forest (above c. $800 \mathrm{~m}$ ). Described as "not uncommon" on Mangole and seen once on Sanana (D. Yong in litt.).

Habitat preferences Most abundant in selectively logged forest, but also common in more degraded forest, and in agriculture. Observed singly or in groups of up to five, generally in the lower storeys to mid-canopy. A vocal species often noted in mixed foraging flocks, associating with Black-naped Monarch Hypothymis azurea, Island Monarch Monarcha cinerascens, Golden Whistler Pachycephala pectoralis, Drab Whistler P. griseonota, Golden Bulbul Ixos affinis, Black-fronted White-eye Zosterops atrifrons, Olive-backed Sunbird Nectarinia jugularis and Black Sunbird $N$. aspasia.

Conservation status Listed as threatened by Collar and Andrew (1988), but no longer considered to be at risk (Collar et al. 1994). As with its larger congener the Slaty Cuckoo-shrike, the species is currently not threatened on Taliabu, occurring commonly in all but the most degraded habitats.

\section{Red-backed Thrush Zoothera erythronota}

Taxonomic status Red-backed Thrush is represented by the nominate race $Z$. $e$. erythronota on Sulawesi, and on Peleng by Z. e. mendeni, the latter known only from one specimen collected in 1938 (White and Bruce 1986). The individuals observed in 1991 on Taliabu showed plumage characters closest to, though not exactly matching, Z. e. mendeni. Thus, the species is represented either in the Banggai and Sula Islands EBA or (perhaps) on Taliabu itself by an endemic subspecies.

Status on Taliabu Scarce (presumed) resident. Only three individuals seen, all in the vicinity of Menanga base camp. These constitute the first records of the species for the Sula Islands. As with other members of the genus this is a shy species and probably easily overlooked.

Habitat preferences All three birds were seen in secondary forest at c.50 m, two in selectively logged forest, the other in heavily degraded forest dominated by large bamboo stands. Seen from ground level up to the canopy of the shorter $(c .20 \mathrm{~m})$ trees in selectively logged forest. On Sulawesi, Red-backed Thrush is found in evergreen forest to 1,000 $\mathrm{m}$ (White and Bruce 1986). However, it was not recorded above $c .50 \mathrm{~m}$ on Taliabu.

Conservation status Listed as near-threatened by Collar et al. (1994). On Taliabu it appears to be at risk. A fuller understanding is needed of its status, susceptibility to disturbance, and habitat requirements, in particular whether it occurs at mid- to high altitudes. 
Henna-tailed Jungle-flycatcher Rhinomyias colonus

Status on Sula Islands Locally common resident, encountered regularly at three lowland study areas. These constitute the first records of the species for Taliabu. Noted by D. Yong (in litt.) on Mangole in 1988 and described as "present" on Banggai by Indrawan et al. (1993). First collected on the Sula Islands in 1897, with three specimens collected on Peleng by Menden in 1938 (White and Bruce 1986).

Habitat preferences Found in lowland forest (both primary and selectively logged), but not exclusively so. Several records were of individuals in heavily degraded forest and on forest/agriculture fringes. Seen once in regenerating secondary forest and heard twice in logged forest on Mangole in 1988 (D. Yong in litt.). Not recorded above $c .300 \mathrm{~m}$ on Taliabu, unlike the two other members of this genus found in Wallacea, Russet-backed Jungle-flycatcher $R$. oscillans on Buru and Streaky-breasted Jungle-flycatcher $R$. addita on Sumba and Flores, both of which are exclusively montane, occurring above $1,000 \mathrm{~m}$. A fairly unobtrusive species, characteristic of its genus, with a rather faint, high-pitched song only audible at close range $(<10 \mathrm{~m})$. Pairs were seen on several occasions, and once a group of four (presumably a family party) were watched together. Not noted in association with any other species.

Conservation status Listed as threatened by Collar and Andrew (1988), revised to near-threatened (Collar et al. 1994). Although not immediately threatened on Taliabu, in the light of the species's apparent restriction to lowland habitats (below c. $300 \mathrm{~m}$ ), it remains at risk from logging activities, particularly as its preferred habitat appears to be undisturbed lowland forest.

\section{Helmeted Myna Basilornis galeatus}

Status on Sula Islands Apparently an uncommon resident, found from sea level to at least 1,000 $\mathrm{m}$. However, noted quite frequently at three of the study sites, including montane forest. Noted on Taliabu and Mangole in 1990 (F. Smiet in litt.). Indrawan et al. (1993) found it "not uncommon" on Banggai in 1991. Described as common in suitable habitat (not specified) on Mangole, although numbers appeared to be small (D. Yong in litt.).

Habitat preferences Encountered most regularly in the least disturbed forest types. However, birds were seen in the largest trees in heavily degraded forest and agricultural areas, often fruiting trees of no commercial value, and also in tall dead or defoliated trees in reedswamp. Although usually observed in pairs, a flock of 22 was found in a fruiting tree in selectively logged forest at $c .400 \mathrm{~m}$ near Menanga base camp. The similar Sulawesi Crested Myna B. celebensis occurs in forest at $300-900 \mathrm{~m}$ in Sulawesi, and in woodlands on Muna and Butung (White and Bruce 1986). Recorded in heavily degraded forest on Banggai in the 1980 os by Bishop (Collar and Andrew 1988). All birds seen on Mangole in 1988 were observed feeding on the berries of a common (unidentified) secondary-growth treelet (D. Yong in litt.). 
Conservation status Listed as threatened by Collar and Andrew (1988), revised to near-threatened (Collar et al. 1994). Despite the fact that in montane forest, much of which is protected from commercial logging, the Helmeted Myna is apparently the most numerous of the islands' suite of key species, it is becoming increasingly vulnerable in the lowlands with the loss of habitat, especially large trees.

\section{Bare-eyed Myna Streptocitta albertinae}

Status on Sula Islands Apparently an uncommon resident. Recorded fairly regularly, but only in small numbers, at three of the six study sites, from sea level to $c .250 \mathrm{~m}$. Menden collected two from the Sula Islands in 1938. Described as "just as common" as Helmeted Myna on Mangole in 1988, and occurring in similar habitat (D. Yong in litt.).

Habitat preferences Noted more frequently in heavily degraded forest and agricultural areas than Helmeted Myna. However, despite its striking appearance, it is an inconspicuous species, and may have been under-recorded in forest habitats. Birds were seen either as singles, or in groups of up to three, but most often in pairs, generally frequenting the largest trees in the more degraded habitats. Not noted above $c .250 \mathrm{~m}$ on Taliabu. On Sulawesi, its congener the White-necked Myna S. albicollis occurs at altitudes of up to $1,000 \mathrm{~m}$ and is common at forest edges and in open woodland (White and Bruce 1986).

Conservation status Listed as threatened by Collar and Andrew (1988), revised to near-threatened (Collar et al. 1994). As with Helmeted Myna, it is probably increasingly susceptible to habitat loss, most especially large fruiting trees, and more at risk than Helmeted Myna due to its apparent altitudinal restriction. A fuller appreciation of its status and habitat requirements is needed, particularly whether it occurs at mid- to high altitudes. At present hunting and trapping of birds (all species) on Taliabu occurs only at very low intensities. However, were the situation to change, both of these striking restricted-rànge mynas might become target species.

\section{Other restricted-range species}

In addition to the key species discussed above, a further eight restricted-range species occur in the Banggai and Sula Islands EBA, six of them on Taliabu (Stattersfield et al. in prep.). White Imperial-pigeon Ducula luctuosa is a common lowland columbid, frequenting secondary forest habitats. In heavily degraded forest below c. $200 \mathrm{~m}$ large gatherings of the species form just prior to dusk. There are two restricted-range parrots in the EBA, Yellow-and-green Lorikeet Trichoglossus flavoviridis and Moluccan Hanging-parrot Loriculus amabilis. Moluccan Hanging-parrot is a lowland species, and is abundant in all but the most degraded of habitats. Yellow-and-green Lorikeet is most numerous in montane forest, perhaps its preferred breeding habitat, but also occurs commonly down to sea level in secondary forest types. The vociferous Golden Bulbul Ixos affinis is abundant in most habitats, both lowland and montane. Rusty-bellied Fantail 
Rhipidura teysmanni is common in montane forest, often encountered in mixed foraging flocks, but is very scarce at lower altitudes. Drab Whistler Pachycephala griseonota is relatively common in secondary lowland forest types and on agricultural fringes.

\section{Subspecies endemic to the Banggai and Sula Islands EBA}

Much subspeciation has occurred in Wallacea, making an important contribution to the overall genetic diversity of the region. The Banggai and Sula Islands are no exception, thus further strengthening the importance of conserving the islands' forests through the establishment of a proposed reserve on Taliabu. Table 4 details the 18 subspecies endemic to the Sula Islands, and a further nine endemic to the Banggai and Sula Islands EBA as a whole.

The majority of these birds occur in lowland habitats (forested and agricultural), although some also occur in montane forest. Most are common, the exceptions being Vinous-breasted Sparrowhawk Accipiter rhodogaster (uncommon), Barred Rail Gallirallus torquatus (uncommon), Moluccan Scops-owl Otus magicus (not recorded during the survey) and Red-backed Thrush (scarce; see above), and all also occur in secondary forest types.

Table 4. Endemic subspecies on the Sula Islands and in the Banggai and Sula Islands EBA

\begin{tabular}{|c|c|}
\hline Species & Range \\
\hline Sulawesi Serpent-eagle Spilornis rufipectus sulaensis & Banggai and Sula Islands EBA \\
\hline Vinous-breasted Sparrowhawk Accipiter rhodogaster sulaensis & Banggai and Sula Islands EBA \\
\hline Barred Rail Gallirallus torquatus sulaensis & Banggai and Sula Islands EBA \\
\hline Slender-billed Cuckoo-dove Macropygia amboinensis sedemica & Sula Islands \\
\hline + Maroon-chinned Fruit-dove Ptilinopus subgularis mangoliensis & Sula Islands* \\
\hline Green Imperial-pigeon Ducula aenea sulana & Banggai and Sula Islands EBA \\
\hline+ Yellow-and-green Lorikeet Trichoglossus flavoviridis flavoviridis & Sula Islands \\
\hline + Moluccan Hanging-parrot Loriculus amabilis sclateri & Sula Islands \\
\hline Moluccan King-parrot Alisterus amboinensis sulaensis & Sula Islands* \\
\hline Golden-mantled Racquet-tail Prioniturus platurus sinerubris & Sula Islands \\
\hline Moluccan Scops-owl Otus magicus sulaensis & Sula Islands \\
\hline Ruddy Kingfisher Halcyon coromanda sulana & Sula Islands \\
\hline Black-billed Kingfisher Pelargopsis melanorhyncha eutreptorhyncha & Sula Islands \\
\hline Variable Kingfisher Ceyx lepidus wallacii & Sula Islands \\
\hline + Golden Bulbul Ixos affinis longirostris & Sula Islands \\
\hline Hair-crested Drongo Dicrurus hottentottus pectoralis & Sula Islands \\
\hline Black-naped Oriole Oriolus chinensis frontalis & Sula Islands \\
\hline Slender-billed Crow Corvus enca magnoli & Sula Islands \\
\hline + Red-backed Thrush Zoothera erythronota & Banggai and Sula Islands EBA* \\
\hline Black-naped Monarch Hypothymis azurea blasii & Banggai and Sula Islands EBA \\
\hline + Rusty-bellied Fantail Rhipidura teysmanni sulaensis & Sula Islands \\
\hline Golden Whistler Pachycephala pectoralis clio & Sula Islands \\
\hline + Drab Whistler Pachycephala griseonota lineolata & Sula Islands \\
\hline Brown-throated Sunbird Anthreptes malacensis extremus & Banggai and Sula Islands EBA \\
\hline Olive-backed Sunbird Nectarinia jugularis robustirostris & Banggai and Sula Islands EBA \\
\hline Grey-sided Flowerpecker Dicaeum celebicum sulaense & Banggai and Sula Islands EBA \\
\hline Black-fronted White-eye Zosterops atrifrons sulaensis & Sula Islands \\
\hline
\end{tabular}

* See text under 'Key species'.

+ Restricted-range species. 
Five passerine species recorded by us in montane forest (Mountain Tailorbird Orthotomus cuculatus, Island Leaf Warbler Phylloscopus poliocephala, Snowybrowed Flycatcher Ficedula hyperythra, Island Verditer Flycatcher Eumyias panayensis and Sulawesi Myzomela Myzomela chloroptera) had not previously been reported from the Sula Islands, and may possibly represent undescribed endemic subspecies. Throughout their Wallacean ranges, all five of these species are represented by separate island subspecies with very little or no inter-island overlap (White and Bruce 1986). However, further rigorous research is needed to confirm this speculation.

\section{Status of other forest birds}

Of the 83 resident bird species previously recorded on Taliabu, 73 were recorded during the course of the survey. The ten species not recorded include four which occur as resident forest-dwellers in other parts of Wallacea, Sulawesi Hawk-eagle Spizaetus lanceolatus, Metallic Pigeon Columba vitiensis, Channelbilled Cuckoo Scythrops novaehollandiae and Moluccan Scops-owl. The former two are both unobtrusive, and Sulawesi Hawk-eagle at least occurs at low densities. Channel-billed Cuckoo occurs as a migrant as well as a resident breeder in Wallacea, and so may have been absent from Taliabu and the Sula Islands during the survey. The status of Moluccan Scops-owl in many parts of Wallacea, including the Sula Islands, needs reviewing. Another unidentified Otus species, distinguishable from Moluccan Scops-owl by call, was regularly heard at a number of sites in both lowland and montane forest types. This bird's calls differ from those of other Otus species in the region, and although not seen well on Taliabu, the same Otus was seen on Mangole and Sanana in 1988 (D. Yong in litt.), and may perhaps be an undescribed species. Other forest nightbirds recorded include Great Eared-nightjar Eurostopodus macrotis and Philippine Nightjar Caprimulgus manillensis. Brown Hawk-owl Ninox scutulata, previously collected on the Sula Islands, was not noted, although it is known as a winter visitor, recorded between October and March (White and Bruce 1986).

Altogether, 22 resident species were recorded for the first time on the islands during the survey, many of these being forest birds. They include Lesser Fisheagle Ichthyophaga humilis, Rufous-bellied Eagle Hieraaetus kienerii, Oriental Hobby Falco severus and Little Pied Flycatcher Ficedula westermanni in addition to those already mentioned.

\section{Mammals on Taliabu}

The mammal fauna of most Moluccan islands is rather depauperate (e.g. White and Bruce 1986, Whitten et al. 1987). Few species occur on Taliabu, but these include the nominate but poorly known subspecies of the globally threatened babirusa Babyrousa babyrussa babyrussa, a pig endemic to Sulawesi, Buru and the Sula and Togian Islands (Macdonald 1993). It is a forest-dweller, and according to local people utilizes the fruits of the commercially valuable dipterocarp Shorea trees as a primary food source. Only one individual was seen, in montane forest at $c .850 \mathrm{~m}$, and local people's answers to a standard questionnaire suggested the species to be declining on the island, at least in the lowlands. Other 
mammals include the Peleng Island cuscus Phalanger pelengensis, endemic to Taliabu and the Banggai archipelago (two individuals were seen during the survey, both in selectively logged lowland forest), a Sus species (probably Javan pig S. verrucosus), and Timor deer Cervus timorensis.

\section{Discussion and recommendations}

Lowland forest is of vital importance to Taliabu's avifauna. The majority of endemic and restricted-range species, as well as most of the endemic subspecies, occur either exclusively or at highest densities in lowland forest. Montane forest, despite being poorer in terms of species composition, also holds a number of restricted-range species (some at higher densities than in lowland forest), and other species restricted to the Moluccas which are only found in high-altitude forest.

It is apparent that most species are able to persist in secondary forest, and that the maintenance of a mosaic of habitats may provide the optimal conservation strategy for the avifauna as a whole. However, primary lowland forest was only found in very small patches, generally along narrow river valley corridors. Although all the key species have been found in secondary lowland forest habitats, relative densities and breeding success in primary and secondary lowland forest still need to be established. Since the birds evolved on the islands when primary forest predominated, it seems likely that most if not all of the endemic avifauna is best adapted to primary forest. Consequently, any remaining areas of unlogged lowland forest must be identified and afforded protection. Follow-up surveys in remaining tracts of this diminishing forest type should aim to evaluate the relative importance of primary lowland forest to the avifauna.

Further work should also include surveys of Taliabu's satellite islands, mangroves and sandy beaches, with a view to their inclusion in the protected area, owing to their potential importance to Sula Scrubfowl and Nicobar Pigeon (forested satellite islands), Great-billed Heron and Malay Sandplover (mangroves and sandy beaches).

Most montane forest is within the protection forest zone (as well as the proposed reserve area) and is therefore protected from commercial logging. However, only c. $20 \%\left(c .415 \mathrm{~km}^{2}\right)$ of lowland forest on Taliabu is currently included within the boundaries of the proposed reserve. In the light of its conservation importance on Taliabu, it would be desirable to conserve a considerably larger area of lowland forest than is currently proposed, and instigate a moratorium on logging activities within such an area.

Controlled human exploitation of the forests may not be incompatible with wildlife conservation on the island. However, initially at least, it would be preferable to gazette the reserve as a cagar alam, as proposed, in which no human activities are permitted. This should be followed up by further studies of the island's birds and of socio-economic issues, both inside and outside the reserve, in order to evaluate the impact of local activities, particularly shifting agriculture. It may then be appropriate to change the reserve's status to one where the local population can play an integral part in its operation. The gazettement of a protected area on Taliabu is part of the BirdLife International Indonesia 
Programme, and proposals for its establishment will be submitted following a further survey period on the island.

\section{Acknowledgements}

We are especially grateful to the staff of BP South-East Asia Ltd, in particular John Swann, Business Development Manager, and Marlina Boerhanoedin, for their help whilst in Jakarta. We extend our warmest thanks to Bas and Like van Balen for their kindness and hospitality throughout, and to our counterparts, Wahyu Raharjaningtrah, Indonesian Institute of Sciences (LIPI), and Hidayat Banjaransari, Directorate-General for Forest Protection and Nature Conservation (PHPA).

We are also very grateful to Sancoyo and Arie Budiman (LIPI); Effendy A. Sumardja, Yus Rustandi, A. L. Pary and Suryafuddin (PHPA); Sutikno, Puslitbang Biologi, Bogor; Sudaryanti, the Zoological Museum, Bogor; Barito Pacific Timber Group (BPTG) especially Gun Mardiatmoko, Slamet Santoso, Edi, Mr Sugianto, Mr Lucas and Ishmail Tari; René Dekker, Derek Holmes, Mohammad Indrawan, Paul Jepson, Umi and Emi Nur Aly, Nggalo, Umi, Ruben, Udin, Ongan and Dindin Ganefuddin; Dr Gary Allport, Alan Pinfold and the staff of Garuda Airlines, and Shunji Usui.

Generous support made this survey work possible, and we thank British Petroleum Company plc, BirdLife International, Fauna and Flora Preservation Society, University of East Anglia Expeditions Committee, Royal Geographical Society/Barclays Bank, British Ornithologists' Union, Albert Reckitt Charitable Trust, Oriental Bird Club, Gilchrist Educational Trust, Elizabeth Stuart Memorial Fund, John Jarrold Charitable Trust, Sir Philip Reckitt Educational Trust, J. and L. A. Cadbury Charitable Trust, People's Trust for Endangered Species, Bird Exploration Fund, Percy Sladen Memorial Fund, Wall Charitable Trust, A. S. Butler Charitable Trust, Dr James Cadbury, Spicers Ltd, University of East Anglia School of Biological Sciences, MAFF Charities, Russell and Mary Foreman (1980) Charitable Trust, and a host of minor and in-kind benefactors too numerous to mention here.

\section{References}

Bishop, K. D. (1989) Little known Tyto owls of Wallacea. Kukila 4: 37-43.

Collar, N. J. and Andrew, P. (1988) Birds to watch: the ICBP world checklist of threatened birds. Cambridge, U.K.: International Council for Bird Preservation (Techn. Publ. 8).

Collar, N. J., Crosby, M. J., and Stattersfield, A. J. (1994) Birds to watch 2: the world list of threatened birds. Cambridge, U.K.: BirdLife International (BirdLife Conservation Series no. 4).

Davidson, P. J., Stones, A. J., Lucking, R. S. and Bean, N. J. (1991) University of East Anglia Taliabu Expedition preliminary report. Unpublished.

Davidson, P. J., Lucking, R. S., Stones, A. J., Bean, N. J., Raharjaningtrah, W. and Banjaransari, H. (1994) Report on an ornithological survey of Taliabu, Indonesia. Unpublished report to BirdLife International.

Dekker, R. W. R. J. (1990) Recent information on Sula Scrubfowl Megapodius bernsteinii. From a letter by Dennis Yong. Megapode Newsl. 4(1): 3-4. 
FAO/UNDP (1981) A national conservation plan for Indonesia, 7: Maluku and Irian Jaya. FO/ INS/78/o51. Bogor, Indonesia: Food and Agriculture Organization.

Gibbs, D. (1990) Wallacea: a site guide for birdwatchers. Bracknell, Berks: Gibbs.

Hartert, E. (1898) List of a collection of birds made in the Sula Islands by William Doherty. Novit. Zool. 5: 125-136.

Hayman, P., Marchant, J. and Prater, T. (1986) Shorebirds: an identification guide to the waders of the world. London: Christopher Helm.

ICBP (1992) Putting biodiversity on the map: priority areas for global conservation. Cambridge, U.K: International Council for Bird Preservation.

Indrawan, M., Fujita, M. S., Masala, Y. and Pesik, L. (1993) Status and conservation of the Sula Scrubfowl (Megapodius bernsteinii Schlegel, 1866) in Banggai Islands, Sulawesi. Tropical Biodiversity 1: 113-130.

Jones, M., Juhaeni, D., Banjaransari, H., Banham, W., Lace, L., Linsley, M. and Marsden, S. (1994) The ecology and conservation of the forest birds and butterflies of Sumba, Indonesia. Report to BirdLife International.

Lambert, F. R. (in prep.) Pittas, broadbills and asities. Mountfield, U.K.: Pica Press.

Lucking, R. S., Davidson, P. J., Stones, A. J. and Bean, N. J. (1992) Status and ecology of the Sula Scrubfowl Megapodius bernsteinii on Taliabu, Maluku, Indonesia. Megapode Newsl. 6(2): 15-22.

Macdonald, A. A. (1993) The babirusa (Babyrousa babyrussa). In W. L. R. Oliver, ed. Status survey and conservation action plan: pigs, peccaries and hippos. Gland, Switzerland: International Union for Conservation of Nature and Natural Resources.

Marchant, S. and Higgins, P. J. (1990) Handbook of Australian, New Zealand and Antarctic birds, $1(B)$ : Ratites to Ducks. Melbourne: Oxford University Press.

RePPProT (1989) Regional Physical Planning Programme for Transmigration. Review of Phase 1 Results: Maluku and Nusa Tenggara. Land Resources Department ODNRI, Overseas Development Administration, London, and Direktorat Jendral Penyiapan Departemen Transmigrasi, Jakarta.

Reynolds, R. T., Scott, J. M. and Nussbaum, R. A. (1980) A variable circular-plot method for estimating bird numbers. Condor 82: 309-313.

Sibley, C. G. and Monroe, B. L. (1990) Distribution and taxonomy of birds of the world. Newhaven: Yale University Press.

Smiet, F. (1982) Threats to the Spice Islands. Oryx 16: 323-328.

Stattersfield, A. J., Crosby, M. J., Long, A. J. and Wege, D. C. (in prep.) Global directory of endemic bird areas. Cambridge, U.K.: BirdLife International (BirdLife Conservation Series).

Wallace, A. R. (1862) List of birds from the Sula Islands (east of Celebes), with descriptions of the new species. Proc. Zool. Soc. Lond. 1862: 333-346.

White, C. M. N. and Bruce, M. D. (1986) The birds of Wallacea (Sulawesi, the Moluccas and Lesser Sunda Islands, Indonesia): an annotated checklist. London: British Ornithologists' Union (Check-list 7).

Whitten, A. J., Mustafa, M. and Henderson, G. S. (1987) The ecology of Sulawesi. Yogyakarta: Gadjah Mada University Press.

PETER DAVIDSON

24 Christchurch Road, Norwich NR2 $2 A E$, U.K.

TONY STONES

32 Hill Street, Norwich NR2 $2 D T$, U.K. 